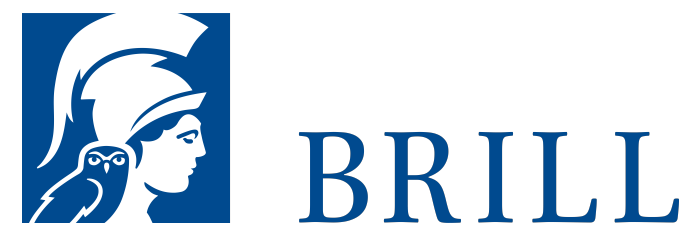

\title{
Practical Reasoning: Its Elements, Practicality and Validity
}

\section{Author: Rebekka Gersbach}

Practical reasoning answers the question »what should I do?« As reasoning it must be a valid combination of premises, as practical it must result in action. We can thus ask what form the premises must have and how they must be combined so as to be valid and practical, i.e. so as to result in rational action. The conventional approach to answering this question results in a dilemma. This book develops an alternative approach which resolves this dilemma. The key to this is to start by analysing the requirements that practical reasoning must meet in order to result in action. With these requirements, we can show that the form of the elements of practical reasoning is that of ends. The validity of practical reasoning will be shown to consist in necessary agreement among ends. The concept of ends and the validity of practical reasoning will be developed on the Basis of a critical assessment of rational choice theory. The resulting contrast is that between fully determined objects of preferences and general ends, between comparison and agreement.

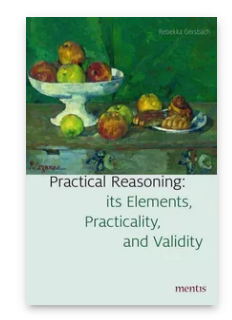

Pages: 169

Seiten

Language:

English

Subjects:

General,

Philosophy

Publisher: Brill | mentis

E-Book (PDF)

Released online: 22 Feb 2016

ISBN: 978-3-

95743-851-5

List price

Paperback

Publication date: 22 Feb 2016

ISBN: 978-3-

95743-०36-6

List price 
For more information see brill.com

Order information: Order online at brill.com +44330 333 0049 | customerservices@brill.com Submission information: brill.com/authors

Titles published by Brill | Fink, Brill | mentis or Brill | Schöningh: +49(o)715413279216| brill@brocom.de 